可視化情報 Vol.21 Suppl. No.1（2０００１２年７月）

船尾後流分布の画像計測

奥野武俊 ${ }^{\circ}$ 大阪府立大学), 成瀬裕希( $\mathrm{IHI}$ ), 西尾 茂 (神戸商船大学)

\title{
Image Measurement of Ship Wake Flow
}

Taketoshi OKUNO, Yuki NARUSE and Shigeru NISHIO

\begin{abstract}
This paper deals with a method of PIV for the wake flow behind a ship model. In order to measure the time-averaged velocity, the statistical method is employed. It is shown that the possibility of measuring the three-dimensional velocity field by one camera and using the only one illumination sheet. In the experiment, a new tracer has been developed to use a large model, $2 \mathrm{~m}$ long ship model in a large circulating water channel, of which the observation section has $6 \mathrm{~m}$ long, $1.5 \mathrm{~m}$ wide and $1.0 \mathrm{~m}$ deep. The diameter and specific gravity of the tracer can be adjusted easily. Fairly large tracer, around $3 \mathrm{~mm}$ diameter, is made to demonstrate its usefulness here. The measured result shows that the measurement method and the new tracer are effective for the experiments.
\end{abstract}

Keywords: New Tracer, Image Measurement, Ship Wake, Circulating Water Channel

\section{1。緒言}

流場に混入されたトレーサ粒子による可視化画像を用 いた流速測定法，いわゆる PIVは，瞬時の流速分布を非 接触で多点同時計測が可能となる方法として注目を集め, 流場の 2 次元計測に関しては相関法や時空間微分法など 一部製品化されているアルゴリズムがあるものの，流場 の 3 次元計測に関しては未だ研究途上にあると言える ${ }^{1)}$.

工学的な立場からは流れの時間平均速度を知る事が重 要であることが多いので，ここでは船尾の後流分布計測 を例として，画像データを統計的に解析する手法に限定 すれば 3 次元流場の時閒平均流速を 1 台のカメラで撮影 された可視化画像から求めることができることを示した。

また，船舶模型を用いた実験では，長さ $2.0 \mathrm{~m}$ 以上の 模型を使うのが一般的であり，大型模型まわりでPIVを 使うためには，それに適したトレーサの開発が必要であ る。ここでは，粒子径や比重を任意に変更できる新しい トレーサ粒子を開発して, 大型回流水槽における画像計 測実験を可能とした。

\section{2. 計測原理}

本計測システムの計測原理は，流場内において局所的に粒 子分布密度が一定であるとみなせる場合には，その点におけ る粒子通過頻度は流速に比例するとの考えを一般化したもの で，結果的に粒子密度に左右されずに，流速の時間平均值を
求めるものである ${ }^{2)}$.

トレーサ粒子によって可視化された画像の輝度值を $f$ ，流 速を観測系に固定した直交座標で $(u, v, w)$ と表し, 画像の輝度 值は流体とともに輸送される物理量と考えれば，輝度変化は 次式で表される.

$$
\frac{\partial f}{\partial t}+u \frac{\partial f}{\partial x}+v \frac{\partial f}{\partial y}+w \frac{\partial f}{\partial z}=0
$$

この点における流線座標 $(\xi, \eta, \zeta)$ とすれば, 流線方向 $\xi$ の速 度成分 $u_{\xi}$ は，次で表わせる。

$$
\frac{\partial f}{\partial t}+u_{\xi} \frac{\partial f}{\partial \xi}=0
$$

ただし，ここでは流場内の照明強度は均一かつ一定と仮定し （1），(2)式の右辺はゼロとしている．ここで，定常流を仮定 すれば，流速の時間平均值（その絶対値）は可視化画像を統 計的に処理することによって得られる。すなわち,

$$
\left|u_{\xi}\right|=\frac{E\left[\left|\frac{\partial f}{\partial t}\right|\right]}{E\left[\left|\frac{\partial f}{\partial \xi}\right|\right]} \text {. }
$$

ここで，E[]集合平均を表しているが，エルゴード性が仮 定できる場合は時間平均と考えて良い.

(3) 式右辺の分子は粒子の通過頻度, 分母は粒子の空間分 布密度になっており, 時間平均流速の絶対值は, その点にお 
ける粒子の通過頻度と粒子の空間分布密度の比により求まる. つまり, 流速の時閒平均の絶対は, 流場の粒子密度に左右さ れずに求められることになる。このことは，たとえ流場が 3 次元であっても，なんらかの方法でこれらの量が求められる なら簡単に時間平均流速が求められることを意味している.

ただし，一般に流線方向は未知であるため，ここでは局所 的な粒子分布密度の等方性を仮定し, 流線方向の輝度の微分 值は，可視化の際に使うシート光上の微分で置き換えられる ものとする。

さて, 計測点における時間平均流速を $(\bar{u}, \bar{v}, \bar{w})$ とすれ ば, $\mathrm{N}$ 個の計測データから求められる支配方程式の残差和Rは, $R=\sum_{i=1}^{N}\left(\frac{\partial f_{i}}{\partial t}+\bar{u} \frac{\partial f_{i}}{\partial x}+\bar{v} \frac{\partial f_{i}}{\partial y}+\bar{w} \frac{\partial f_{i}}{\partial z}\right)^{2}$

となる。ここで，(5) 式の残差和 $\mathrm{R}$ を最小にする $(\bar{u}, \bar{v}, \bar{w})$ は

(6)式の条件を満足することになる.すなわち

$\frac{\partial R}{\partial \bar{u}}=\frac{\partial R}{\partial \bar{v}}=\frac{\partial R}{\partial \bar{w}}=0$

したがって,これから (7)式に示すような連立方程式が得 られる。

$[A]\left(\begin{array}{l}\bar{u} \\ \bar{v} \\ \bar{w}\end{array}\right)=\left(\begin{array}{l}-\sum_{i=1}^{N}\left(\frac{\partial f_{i}}{\partial x} \frac{\partial f_{i}}{\partial t}\right) \\ -\sum_{i=1}^{N}\left(\frac{\partial f_{i}}{\partial y} \frac{\partial f_{i}}{\partial t}\right) \\ -\sum_{i=1}^{N}\left(\frac{\partial f_{i}}{\partial z} \frac{\partial f_{i}}{\partial t}\right)\end{array}\right)$

ここで, $[A]$ は (8)式で表わされる行列であり，

$[A]=\left(\begin{array}{ccc}\sum_{i=1}^{N}\left(\frac{\partial f_{i}}{\partial x}\right)^{2} & \sum_{i=1}^{N}\left(\frac{\partial f_{i}}{\partial x} \frac{\partial f_{i}}{\partial y}\right) & \sum_{i=1}^{N}\left(\frac{\partial f_{i}}{\partial x} \frac{\partial f_{i}}{\partial z}\right) \\ \sum_{i=1}^{N}\left(\frac{\partial f_{i}}{\partial y} \frac{\partial f_{i}}{\partial x}\right) & \sum_{i=1}^{N}\left(\frac{\partial f_{i}}{\partial y}\right)^{2} & \sum_{i=1}^{N}\left(\frac{\partial f_{i}}{\partial y} \frac{\partial f_{i}}{\partial z}\right) \\ \sum_{i=1}^{N}\left(\frac{\partial f_{i}}{\partial z} \frac{\partial f_{i}}{\partial x}\right) & \sum_{i=1}^{N}\left(\frac{\partial f_{i}}{\partial z} \frac{\partial f_{i}}{\partial y}\right) & \sum_{i=1}^{N}\left(\frac{\partial f_{i}}{\partial z}\right)^{2}\end{array}\right)$

であるが，流場に局所的等方性を仮定し，粒子が円形と なっている可視化画像を考え、輝度值は時間に対してラ ンダムな值となることを考えると, $[A]$ の対角成分以外の 項は零になるので，速度は簡単な演算で求められる。た だ. 1 枚のシート光を用いる場合は, 主流方向の輝度值 の微分值を求める事は不可能なので，ここではまず(3) 式から速度べクトルの絶対值を求め, (8) 式を使って面内 速度分布を求めると, その差は主流方向の速度成分とな るので, これによって船尾の後流分布が求めた。
3. 実験システム

船尾後流分布の計測をするために, 本研究で開発した システムの概要をFig. 1 に示す。本計測システムでは一 様流に対して垂直にシート光面を作り，流体中にトレー サ粒子を混入してシート光を通過する際の散乱光を, 鏡 を介して観測部側面より CCD カメラで撮影した。 また， データ処理を簡単にし，実用的な計測を実現するため, CCD カメラで撮影される画像は計算機に直接取り込まれ るとすぐに統計值の計算を行い，その場で計測結果を画 面に出力できるようにした。これにより，画像データは 一度に最低 2 枚のみ保存すれば良く, 計測時間は短縮さ れる。

まず，本計測システムの有意性を確かめるために，小 型模型を小型回流水槽で実験を行った。この場合のシー ト光の厚みは $2 \mathrm{~mm}$, 一様流速は $0.5 \mathrm{~m} / \mathrm{s}$ に設定し, トレー サ粒子の直径は $0.25 \mathrm{~mm}$ のものを使用した。船体模型は, 全長 $400 \mathrm{~mm}$ のSeries60（ $\mathrm{Cb}=0.6 ）$ を用いた.

原理的に 2 枚の画像取り込み間隔内に，ある粒子がシ 一ト光上を 1 画素以上移動すれば, 粒子の通過頻度を正 確に求めることができないので，見かけ上この時間間隔

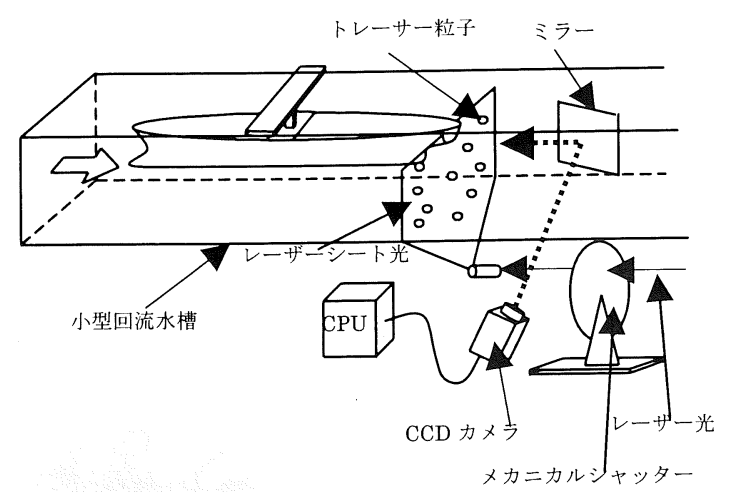

Fig.1 Experimental Setup

を短くする工夫を行った，すなわち、レーザービームラ イン上に回転円盤を利用したメカニカルシャッターを設 け，2枚の画像取り込み間隔を任意に変化できるように し，画像取り込み間隔を $1 / 1000$ 秒とした。この簡易なシ ステムを用いてアルゴンレーザによる連続光によって， パルスレーザーやAOM を用いたのと同じ効果を得た.

後述する大型回流水槽における実験もほぼ同じシステ ムであり，水槽および模型に対応して相対的に大きなも のとしている。ただし，CCD カメラらアクリル製の透明 ボートに搭載して, 鏡を介さずに船尾後方から直接撮影 する方法を使った。

\section{4. 計測結果}

画像計測に先立って，従来からこの種の計測によく用 いられているピトー官による計測を行った。Fig. 2 はそ の結果である。本実験で用いたピト一官の直径は $3 \mathrm{~mm} の$ 


\section{船尾後流分布の画像計測}

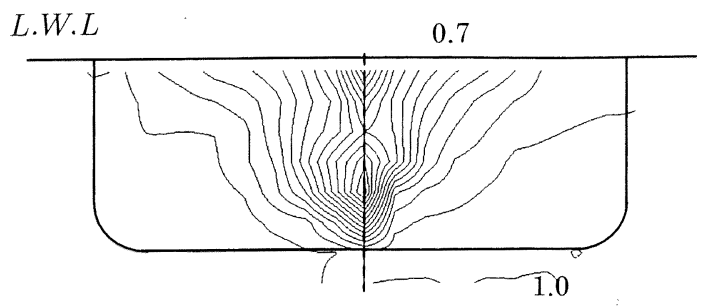

Fig.2 Measured by Pitot Tube

JIS 型で, プロペラ面内の $21 \times 8$ 点で行い, 合計 168 点 のデータを得た。この実験に要した計測時間は約 11 時間 であった。

Fig. 3 は画像計測によって得られた後流分布の結果で ある。この計測で用いた画像データは 5 万組で, 計測時 間は約 3 時間であった。この結果をFig. 2 と比較すれば, 船体中央付近で流速が最も遅くなる様子など, 瘦型船に 見られる縦長の後流分布はかなりよく捕らえられている ことがわかる。もちろん, 分布の詳細には異なるところ もあり，特に流速の大きなところでの計測精度について は十分でない印象を与えている。しかしながら，もとも と計測精度よりも短時間計測を目指して開発した本計測 システムの妥当性は確認できたと思われる.

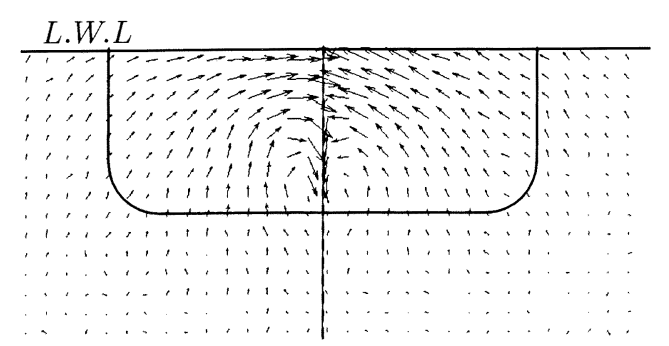

Fig.4 Cross Flow Distribution

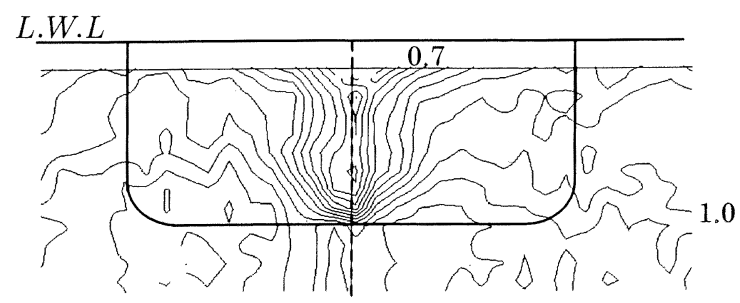

Fig.3 Measured by Images

また,プロペラ面内の 2 次流れはFig. 4 に示寸通りで, これも瘦型船の典型的な速度分布となっている。

\section{5. 大型回流水槽における船尾後流分布}

次に, 前述した小型回流水槽における実験を基に, 本 研究の最終目標である大型回流水槽における船尾後流の 計測結果について述べる.
ここで用いた大型回流水槽は，その観測部の長さ $6 \mathrm{~m}$. 幅 $1.5 \mathrm{~m}$, 深さ $1.0 \mathrm{~m}$ で, ここに長さ $2 \mathrm{~m}$ の船体模型をおい て実験する。一様流速は， $u_{\curvearrowright}=0.75 \mathrm{~m} / \mathrm{s}$ であるが，これ はこの種の実験における標準值と考えてよく, $\mathrm{Fn}=0.17$, $\mathrm{Rn}=1.32 \times 10^{6}$ である。供試模型は典型的な肥大船型の SR196A 模型（Cb=0.802）である。

\section{1 新しいトレーサの開発}

大型回流水槽において，前節までに述べた画像計測法 を用いるためには,それに適したトレーサが必要である。 ここでは，他の実験にも用いることを一つの目標に，以 下の要件を考えた。

1）粒子径は任意に変更できること

2）できるだけ簡単に製作できること

3）大きな粒子径のトレーサもできること

4）比重は調節可能で, ほぼ 1.0 であること

5）蛍光性を持たすことができること

6）水槽の水と一緒に排水可能であること （人体や環境に影響の無い物質）

これらの用件を満たす可能性のある物質について調查 した結果，アルギン酸ナトリウムと塩化カルシウムを用 いた，いわゆる「人エイクラ」の製作手法 ${ }^{3)}$ を応用する のがよいことが分かり，以下のような手法で新しいトレ 一サ粒子を製作した。

製作手法は，マイクロカプセルの製法の一つとして知 られているもので，アルギン酸ナトリウム溶液を塩化力 ルシュウム溶液に滴下寸るものである。滴下用の細管の 直径を変えることで任意の粒子径を得ることができ，ア ルギン酸ナトリュウム溶液に適当なオイルを加える事で 粒子の比重を調整することが可能である。また, 蛍光顔 料を混合すれば，十分な輝度を有する粒子を作ることも でき，ここでは有機顔料（シンロイヒ）を使った。

1 リットルの $1.5 \%$ のアルギン酸ナトリム溶液に対し て, $135 \mathrm{~m} 1$ のオイルと 7 グラムの顔料を加え, $10 \%$ 塩化力 ルシュウム溶液に, 水頭圧約 $1.0 \mathrm{~m}$ 程度の圧力をかけた直 径約 $1 \mathrm{~mm}$ の細管から滴下した。これによって, ほぼ比重 1.0 , 直径 $3 \mathrm{~mm}$ の粒子を作る事ができた。細管の直径を変 更し, 細管にかかる圧力を変更することで, 滴下速度や 粒子径を任意に変更できることを確認した。

直径の大きな粒子トレーサは，流れに対する追従性が 悪くなることが心配されるが，ここでは，これまでに開 発した計測プログラムをそのまま使うために, 従来の実 験装置をほぼ比例的に大きくして, 粒子径をほぼ $3 \mathrm{~mm}$ と 決めた。ただ，粒子径の大きなトレーサで比重を 1.0 す ることはかなり難しいと思われるので，ここでは強いて 大きなものによる実験を試みるといら動機もあった。

なお，このトレー州粒子は，「人ロイクラ」として市販 されているものとほぼ同じものであり, 無害で水槽の水 と一緒に雨水路に排水しても問題無い事を確認した。 


\section{2 実験結果}

この実験における供試模型船は，船尾渦が比較的大き く, 特徵的な渦状の面内速度分布を示す肥大船 SR $196 \mathrm{~A}$ 模型である。大型回流水槽の観測空から船体までの距離 はほぼ $1 \mathrm{~m}$ と,かなりあるため, レーザ光の減衰が大きく， 粒子像の輝度が低くなる. そのためにシート光を通過す る粒子の認識率が小さくなるため，計測画像数をかなり 取る必要があることがわかった。 Fig. 5 は, 流速ベクト ルの絶対值を濃淡分布で表し，面内速度をべクトルとし て表示したものである。この結果を得るための計測時閒 は 9 時間, 解析画像の合計枚数は 15 万枚である.

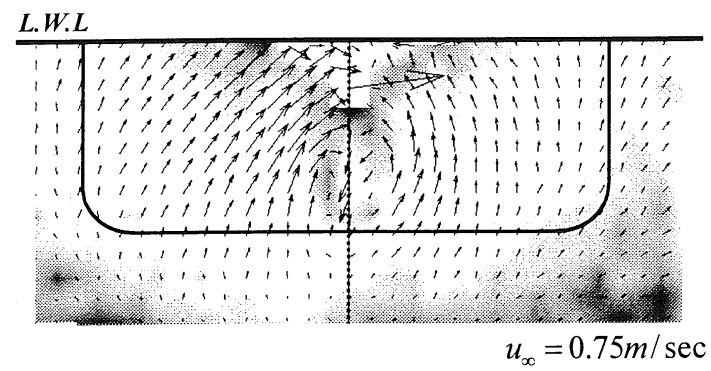

Fig.5 Measured Result in Large CWC

図を見てわかるように，面内速度べクトルは典型的な 渦状分布となっているが，速度べクトルの絶対值に対す る等高線を描いた Fig. 6 から分かるように，小型回流水 槽における計測例に比較して滑らかな分布形状は得られ ておらず, プロペラ位置付近では若干高い值となるなど, 不自然さもある。これらは小型回流水槽での実験に比べ て, 粒子の通過頻度が十分でないことが大きな原因と思 われる。

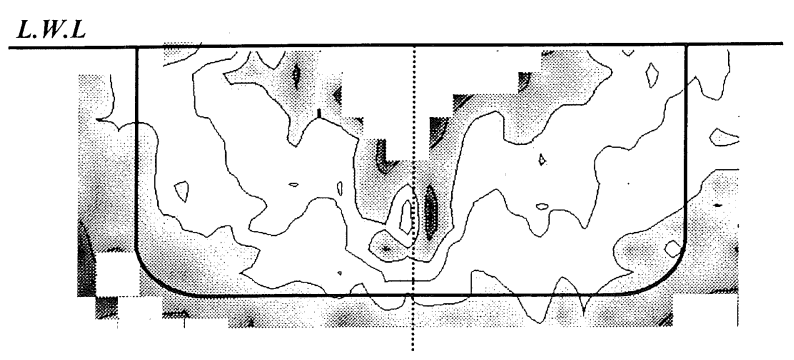

Fig.6 Absolute Value of Velocity

Fig. 7 は, 2 節で述べた手法で船の進行方向の速度成分 を求めて，等高線として示したもので，これがいわゆる 船尾伴流分布になる。この図は，船尾後流域における流 場の特徴を十分に捉えており, 本計測システムは大型回 流水槽における実験に対しても，十分有効であることを 示している

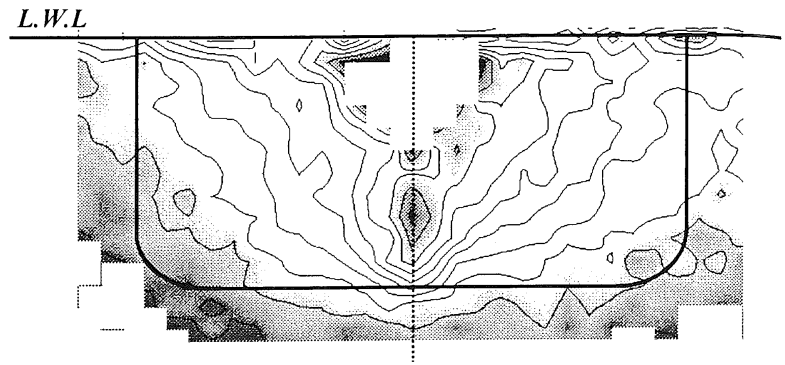

Fig.7 Wake Distribution

6. 結言

本研究では, 従来から開発してきた船尾後流分布を計 測するための，画像データの統計的解析手法を拡張すれ ば，1 枚のシート光面による計測データから 3 次元流場 の速度成分の時間平均值を求めることが可能であること を示し，計測のための実験システムを開発した。

小型回流水槽を使って使って船尾後流を画像計測し, ピトー管による実験結果と比較して, 本システムの有効 性を確認した。

次に, 同様の実験を大型模型と大型回流水槽を使って 行うために適当なトレーサ粒子の開発を行い。粒子直径 や比重を任意に変更できる, 新しいトレーサ粒子を開発 した。ここでは，比較的粒子径の大きなもので，比重を ほぼ 1.0 のものを作成し，レーザに対する蛍光性も十分 持たせることができた。その結果, ほぼ満足すべき結果 が得られた。今後, 粒子径の選び方や, 蛍光顔料の工夫 などによって計測精度も上げることができるものと期待 される。

\section{参 考 文 献}

1）平工 良三, 鈴木 敏夫 : 高速ビデオカメラを用いた連続 画像デー夕処理による三次元流速測定法の開発, 可視化情 報学会誌 Vol.19 Suppl. No 2

2）西尾 茂, 奥野武俊, 平田奈美 : 統計解析手法を用いた流 場の画像計測システムの開発（第 3 報）- 3 次元速度場計 測への応用一, 関西造船協会誌, 第 228 号, pp. 59-65, 1997

3 ) 近藤 保, 小石 真純: マイクロカプセル: 三共出版, 1997 